\title{
A Review of the Eighth District's Banking Economy in 1986
}

\author{
Lynn M. Barry
}

D uring a year of continuing economic expansion, banks in the Eighth Federal Reserve District showed moderate earnings improvement in 1986. ${ }^{1}$ Reported earnings rose at many District banks: profitable investment decisions and lower interest rates, which reduced the cost of deposit liabilities, more than offset loan losses. Though most institutions are profitable and in good financial condition, agricultural and other credit problems continue to trouble some District banks.

Bank failures, while up sharply nationwide, declined in the Eighth District. Nationally, 138 banks insured by the Federal Deposit Insurance Corporation (FDIC) failed in 1986, the largest number to fail since the FDIC was formed in 1933. Five banks in the District failed in 1986 compared with six in 1985 - one national bank and four state banks not members of the Federal Reserve System. ${ }^{2}$ These five banks represent less than 1 percent of the total number of banks in the District and had combined total assets of $\$ 72.7$ million, only 0.2 percent of all District bank assets. ${ }^{3}$

This article examines the overall condition of Eighth District banks by assessing several measures of bank

Lynn M. Bary is an economist at the Foderal Reserve Bank of St. Louis. Rosemarie Mueller provided research assistance.

'The Eighth Federal Reserve District consists of the following states and parts of states:

Arkansas, entire state; llinois, southern 44 counties; Indiana, southen 24 counties; Kentucky, westem 64 counties; Mississippi, northern 39 counties; Missouri, eastern and southern 71 counties and the City of St. Louis; Tennessee, western 21 counties.

${ }^{2}$ Of the five District commercial bank failures in 1986, three were agricultural banks (banks with more than 25 percent of their total loans to farm borrowers).

see Carraro (1986/1987). performance, including earnings, asset quality and capital adequacy. An evaluation of these measures provides useful information on the financial condition, compliance with banking regulations and statutes, and operating soundness of the regional banking industry.

\section{EARNINGS}

The number of District banks with negative earnings fell last year from 127 banks in 1985 to 113 (or from 9.2 percent to 8.5 percent of District banks) in 1986. A notable improvement occurred in the smallest bank category (less than $\$ 25$ million in assets), in which the number of banks with negative net income declined by seven.

Two key measures of bank earnings and managerial performance are the return on assets (ROA) ratio and the return on equity (ROE) ratio. The ROA ratio, calculated by dividing a bank's net income after taxes by its average assets, gauges how well a bank's management is employing its assets. The ROE ratio, obtained by dividing a bank's net income by its equity capital, indicates the return on the shareholders' investment."

District banks generally had higher returns on assets and equity in 1986 than in the previous two years. As table 1 indicates, Eighth District banks earned an average 0.90 percent ROA and an 11.53 percent ROE in 1986, both up from their 1985 performance. The 1986 figures for District banks compare favorably with the national average ROA of 0.64 percent and ROE of 9.83 percent.

"Equity capital includes common and perpetual preferred stock, surplus, undivided profits and capital reserves. 


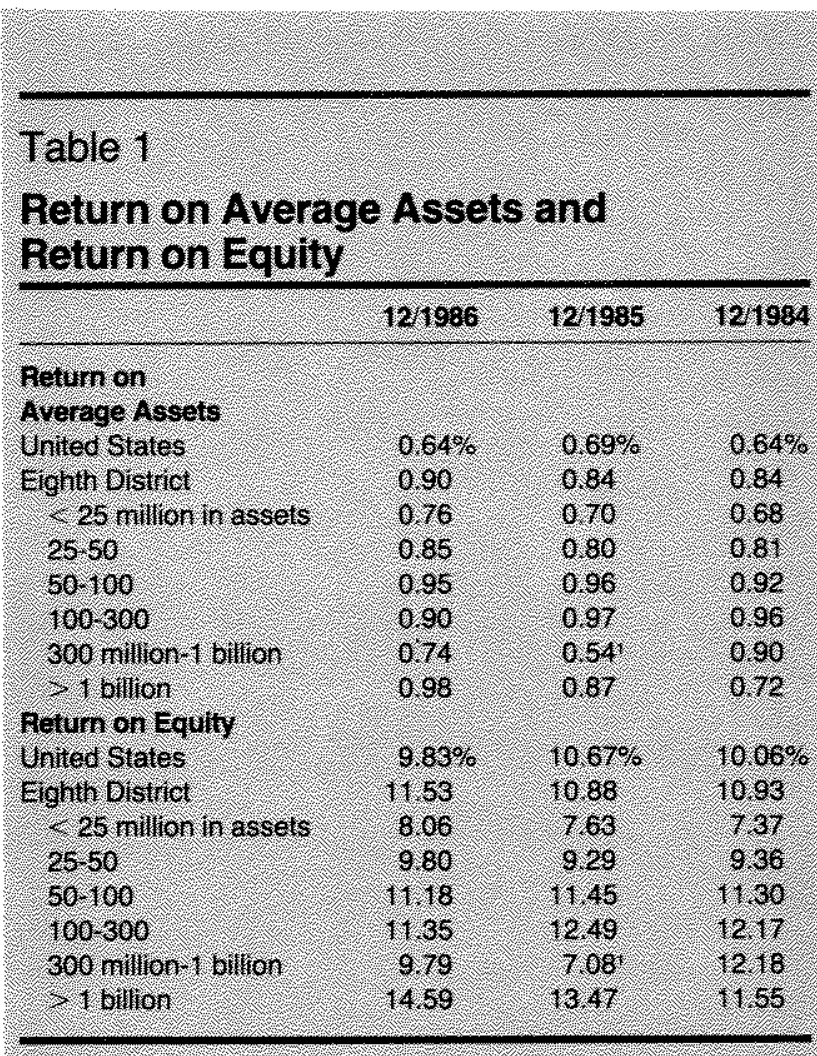

netlects stibstanilat ban losses that bccuired when a now defunct govemnent securilies group was unaile 10 hondor the obligations of a large comnercal bank n A karsas.

sovnce. Federal Deposit insurance comoration. Sonsol caled Heroits of Centition and Thoone for insurec Comnereial Banks; $1084-86$

Increased profitability at District banks arose primarily from both wider net interest margins and improved asset quality (which resulted in fewer chargeoffs). Net interest margin, roughly similar to a business' sales margin, measures the spread between a bank's interest income and interest expense. The decline in interest rates during 1986 reduced debtservicing costs and increased the lending spread compared with the previous two years. As table 2 shows, the average spread between interest income and expense as a percent of average assets is 4.05 percent in the District, compared with 3.77 percent in the nation.

Bank eamings in the District were boosted during the past year as the largest banks continued to expand their noninterest sources of income by pricing more of their products explicitly. Major income sources included fee income associated with deposit, trust and mortgage services. Smaller banks, however, have had much slower growth of noninterest income. As table 3

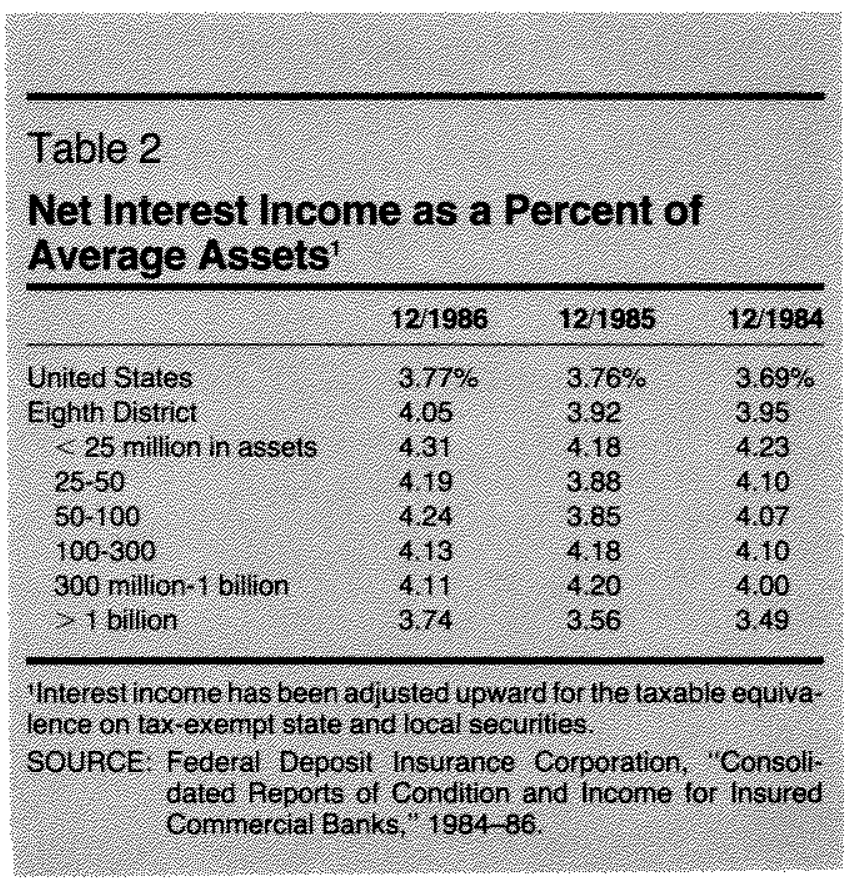

Table 3

Noninterest Income as a Percent of Average Assets

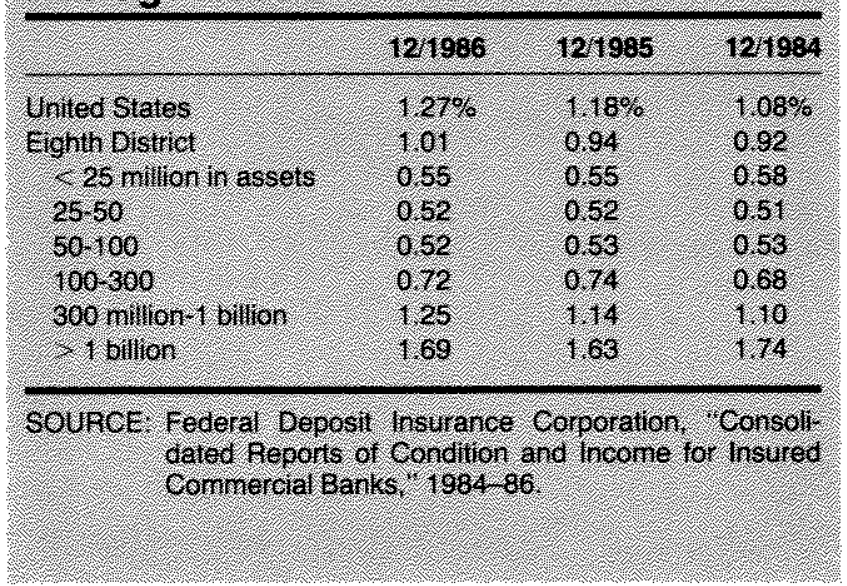

indicates, noninterest income relative to average assets has remained essentially unchanged at District banks with assets less than $\$ 100$ million.

\section{ASSET QUALITY}

Asset quality is a primary factor influencing the banking industry's earnings pattern. Concern among regulators about the quality of bank assets has increased in recent years, given its direct effect on bank profitability. 


\begin{tabular}{|c|c|c|c|}
\hline \multicolumn{4}{|c|}{ 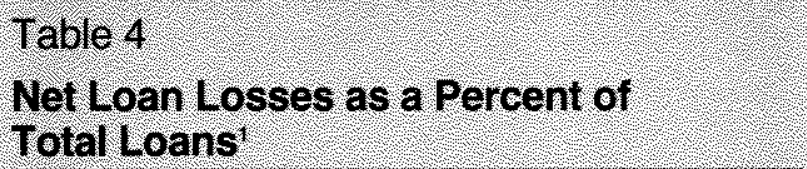 } \\
\hline & 121986 & 121985 & 121984 \\
\hline 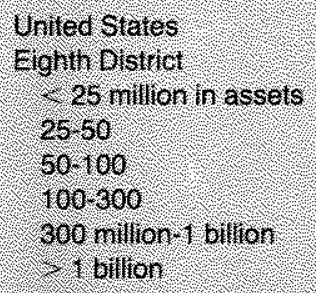 & $\begin{array}{l}093 \% \\
0.86 \\
1,24 \\
1,6 \\
09 \\
0.95 \\
0.68 \\
0.57\end{array}$ & $\begin{array}{l}0.81 \% \\
0.89 \\
15 \\
39 \\
09 \\
072 \\
070 \\
079\end{array}$ & $\begin{array}{l}0.72 \% \\
0.60 \\
1,75 \\
0.96 \\
0.69 \\
0.47 \\
0.39\end{array}$ \\
\hline \multicolumn{4}{|c|}{ 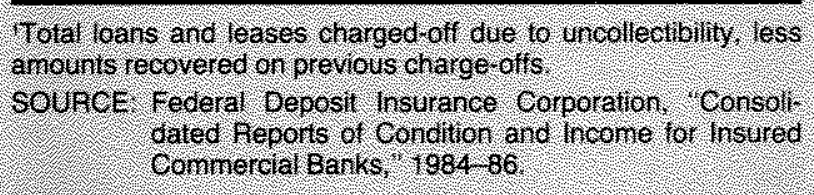 } \\
\hline
\end{tabular}

Changes in asset quality typically are monitored by two indicators. The ratio of net charge-offs to total loans is a traditional measure of loan quality, showing the percentage of net loans (adjusted for recoveries) actually written off as losses.

The second measure of asset quality, the nonperforming loan rate, indicates the level of problem loans as well as the potential for future loan losses. Problem assets include the following components: loans greater than 89 days past due, nonaccrual loans and renegotiated loans.

Since year-end 1982, all FDIC-insured commercial banks have reported delinquencies (loans more than 30 days past duel, nonaccrual and renegotiated loans, and loan charge-offs on a quarterly basis. Nonaccrual loans are those with scheduled payments due and unpaid for more than 90 days, for which full payment. of interest or principal is unlikely. Nonaccrual loans may also include loans that the bank decides to classify as nonaccrual that is, the recent decisions by major banks with respect to Brazilian loans). Renegotiated loans are loans that have been restructured to provide a reduction of either interest or principal because of a deterioration in the borrower's financial position. The information now reported permits a comprehensive analysis of the degree and breadth of a bank's loan quality problems.

As table 4 indicates, the ratio of net loan losses to

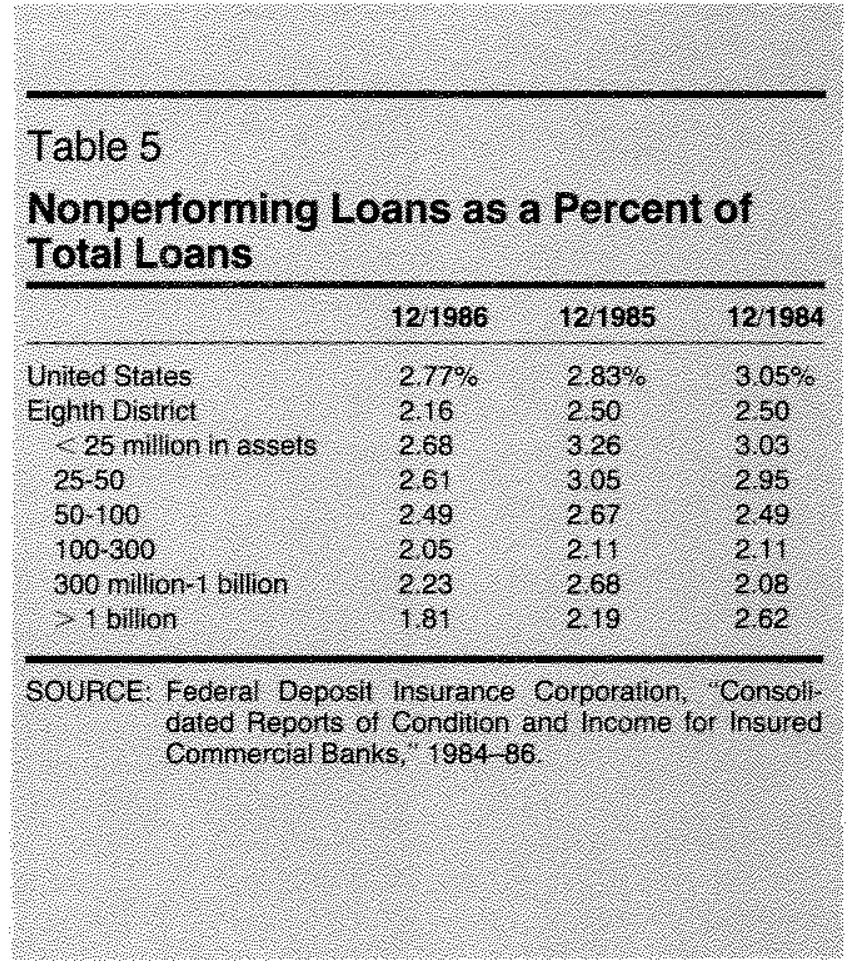

total loans was lower at year-end 1986 than one year earlier for all size categories in the District except for banks in the $\$ 100$ million- $\$ 1$ billion asset range. Small banks, those with assets less than $\$ 25$ million, showed a large decline during this period, with the charge-off ratio falling from 1.51 percent to 1.24 percent. For the largest banks in the Eighth District, the charge-off ratio fell only slightly. Chart 1 compares loss rates of different loan types. As one can see from the chart, the loss rate was highest for District banks' agricultural loans, with commercial loans a close second

As table 5 shows, the nonperforming loan rate decreased in the District during 1986, falling from 2.50 percent in 1985 to 2.16 percent in 1986. This pattern was mirrored across all size categories of District banks.

Because of deteriorating asset quality during the past several years, banks in the Eighth District and the nation have increased their allowance for loan losses as a share of their total loans outstanding. This action has been taken as a precautionary measure to absorb expected future loan losses. Table 6 indicates that medium-size banks, in particular, increased theirloan loss allowance account in response to an acceleration in their level of nomperforming loans. As a percent of total loans, Eighth District banks' loan loss allowance increased from 1.31 percent at year-end 1985 to 1.39 percent in 1986, while nationally this ratio rose from 1.42 percent to 1.62 percent. 


\section{Chart 1 \\ Loan Loss Ratios by Category}

Eighth District

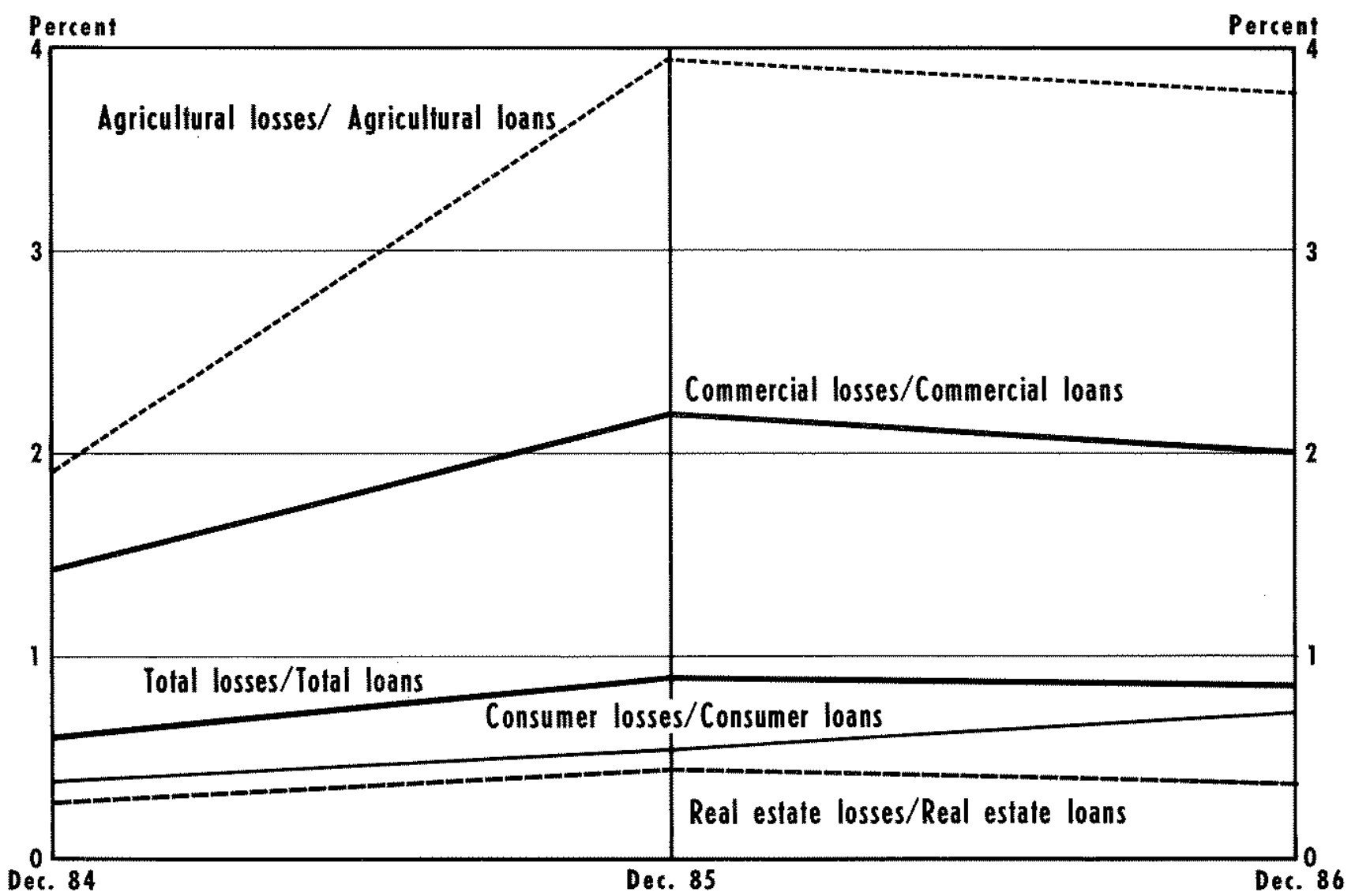

\section{Table 6}

\section{Allowance for Loan Losses as a Percent of Total Loans}

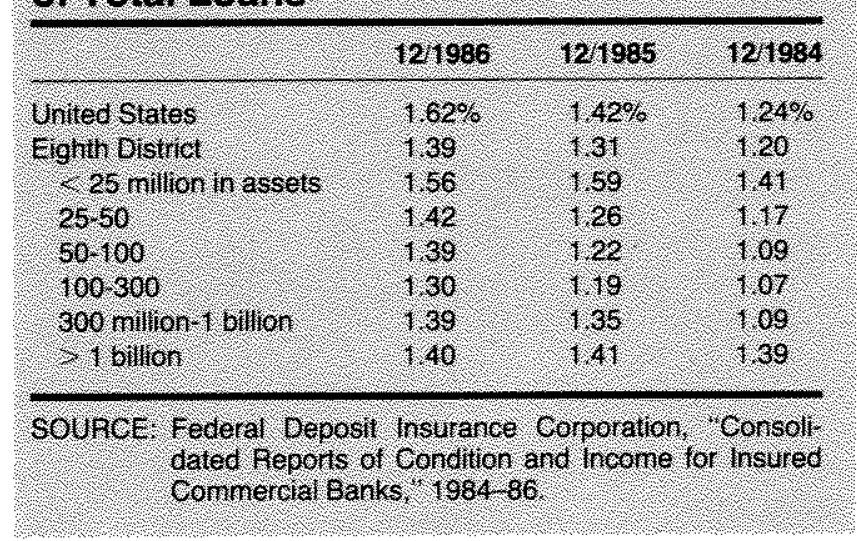

\section{CAPITAL ADEQUACY}

Capital - the difference between a bank's assets and its liabilities - supports a bank's operations and provides a cushion for losses that may arise. Bank capital traditionally has been seen as a way to protect a bank and its creditors from failure. For a given quality of assets, the lower the capital base, the greater the risk of insolvency. The level of capital also serves to maintain public confidence in the soundness of indi. vidual banks and the banking system as a whole.

The amount of capital by itself does not necessarily provide useful information to regulators; capital must be measured relative to those balance sheet items whose fluctuations bank capital is intended to cushion. Regulators generally are concerned with the amount of primary and total capital relative to some 
measure of the bank's asset base..$^{5}$ The regulatory agencies do not assume that a bank's capital is adequate simply because it meets the minimum capital requirements. Banking organizations whose operations involve higher than normal degrees of risk are expected to hold additional capital. Areas that merit particular attention in analyzing risk are the loan and investment portfolios, the level of liquid assets in relation to total assets, the volume and nature of offbalance sheet risk exposure, the level and character of intangible assets and the extent and nature of all nonbanking activities. ${ }^{6}$ Federal banking regulators will require specific banks to meet higher capital ratios if their assets are considered to be risky, that is, to have a relatively high probability of significant decline in value. ${ }^{7}$

Improvement in bank capital ratios in recent years is apparent throughout the range of institutions. One major reason for the increased levels of capital has been the adoption of capital adequacy guidelines by the three federal agencies that regulate U.S. commercial banks: the Federal Deposit Insurance Corporation, the Federal Reserve System and the office of the Comptroller of the Currency. In November 1983, Congress enacted the International Lending Supervision Act of 1983, which directed the federal banking agencies to establish minimum levels of capital for banks. As a result, these agencies have set minimum standards of 5.5 percent primary capital to assets and 6.0

\footnotetext{
5The components of primary capital as reported in the FDIC Consolidated Report of Condition and income are: common stock, perpetual preferred stock, surpius, undivided profits, contingency and other capital reserve, qualifying mandatory convertible instruments, allowance tor loan and lease losses, and minotity interests in consolidated subsidiaries, less intangible assets excluding purchased mortgage servicing tights. (For the purposes of this paper, only the goodwill portion of intangible assets was deducted.) Secondary capital is limited to 50 percent of primary capital and includes subordinated notes and debentures, imited-life preferred stock and that portion of mandatory convertible securites not included in primary capital. Each bank's secondary capital is added to its primary capital to obtain the total capital level for regulatory purposes.

${ }^{6}$ Off-balance sheet activities are discussed most often in terms of loan commitments, standby and commercial letters of credit, toreign exchange contracts, financial futures and forward contracts and interest rate or foreign currency swaps. These transactions all involve contracts for the future purchase or sale of assets and include relatively new activities for banks.

The Federal Reserve Board has developed a proposal for the adoption of risk-based capital standards. The proposed guideline would assign weights based on relative risk to assets and certain offbalance sheet items. The sum of these weighted asset values is the weighted risk asset total against which actual primary capital would be compared.
}

sSee Gilbert, Stone and Trebing (1985).

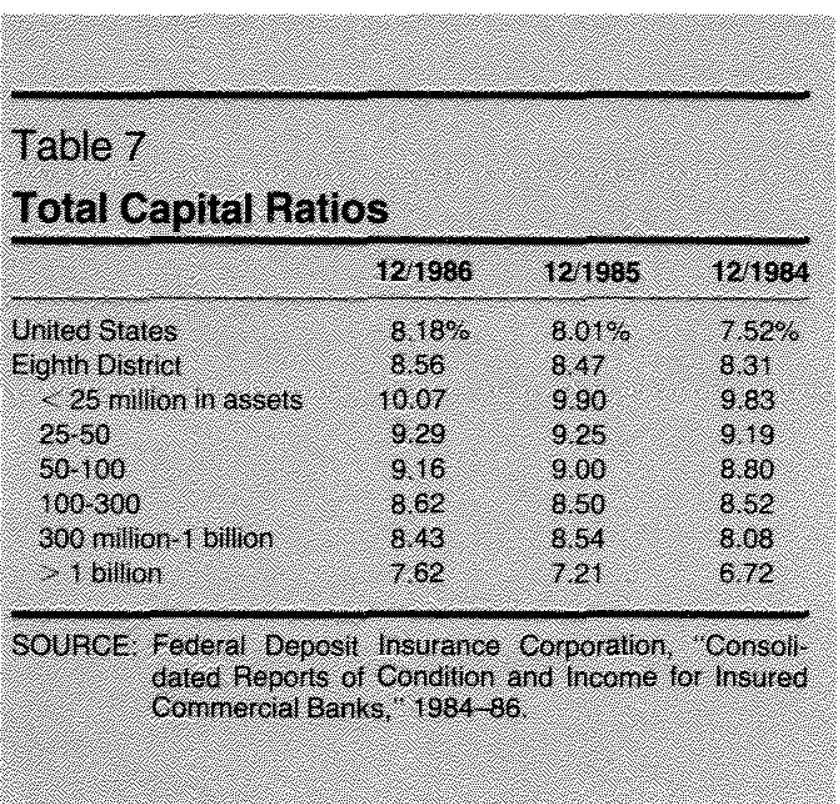

percent total capital to assets. The minimum capital ratios are the same for all federally supervised banking organizations regardless of size, type of charter or membership in the Federal Reserve System.

As indicated in table 7, total capital ratios are well above the minimum standards established by the bank regulatory agencies both for banks in the Eighth District and the banking industry as a whole. The average total capital ratio the sum of the individual banks' total capital divided by the sum of the individual banks' total adjusted assets) was 8.56 percent for Eighth District banks compared with 8.18 percent for all U.S. commercial banks. In 1986 , total capital ratios rose across all asset size ranges except those District banks in the $\$ 300$ million to $\$ 1$ billion range. For banks with assets greater than $\$ 1$ billion, the average total capital ratio rose from 7.21 percent in 1985 to 7.62 percent in 1986. As of December 1986, approximately 1.6 percent of all District banks did not meet the minimum regulatory total capital standards, while for the nation, slightly more than 3.8 percent of the commercial banks had deficient total capital ratios.

\section{SUMMARY}

Overall, District commercial banks showed improved profitability in 1986, outperforming their peers across the nation. District banks, in general, earned higher returns on assets and equity than in the previous two years, Net interest margins also improved at banks in the region.

Asset quality continues to be a major factor influencing the banking industry's level of earnings. 
While the ratios of loan charge offs and nonperforming loans to total loans declined in the District, banks did, however, increase their allowance for loan losses in order to absorb additional loan losses in the future.

A majority of Eighth District banks improved their capital ratios during 1986 and are positioned well above the minimum standards established by bank regulators. On the whole, District banks outperformed the nation in terms of their capital adequacy position.

\section{REFERENCES}

Barry, Lynn M. "1985 - Eighth District Bank Petomance," Banking and Finance - An Eighth District Perspective (Spring 1986).
Board of Govenors of the Federal Reserve System. Press Release, Capital Adequacy Guidelines, April 18, 1985.

Carraro, Kenneth C. "Uneven Trends in Eighth District Bank Protitability," Banking and Finance - An Eighth District Perspective (Spring 1985).

. "Bank Failures in the 1980 s - Another Perspective," Banking and Finance - An Eighth District Perspective (Winter 1986/1987).

Gilbert, R. Alton, Courtenay C. Stone, and Michael E. Trebing. "The New Bank Capital Adequacy Standards," this Review (May 1985).

Waldrop, Ross. "Commercial Bank Performance in 1985," Banking and Economic Review, Federal Deposit Insurance Corporation. Vol. 4, No. 3, April 1986, pp. 19-24.

"Commercial Banking Performance, Mid-Year 1986," Banking and Economic Review, Federal Deposit Insurance Corporation, Vol. 4, No. 8, November/December 1986, pp. 13-19. 